\title{
Soil carbon and nitrogen under different land-use and landscape loca- tions in central Brazil
}

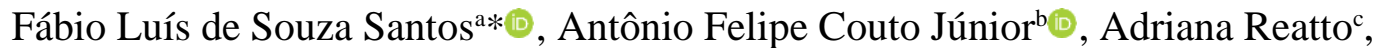 \\ Éder de Souza Martins ${ }^{\mathrm{d}}$, Arminda Moreira de Carvalho ${ }^{\mathrm{d}}$, Gabriela Bielefeld Nardoto ${ }^{\mathrm{a}} \odot$ \\ a Universidade de Brasília, Brasil \\ b Universidade de Brasília, Brasil (in memorian) \\ c Embrapa, Secretaria de Pesquisa e Desenvolvimento, Brasil \\ d Embrapa Cerrados, Brasil \\ *Autor correspondente (fabio.luis92@gmail.com)
}

\section{N F O}

\section{Keyworks}

Brazilian savannas

stable isotopes

soil organic matter

carbon stock

geomorphology

\begin{abstract}
A B S T R A C T
In Central Brazil, plateaus, the most common geomorphologic form, have been undergoing intense conversion from native vegetation to pasture and agriculture in recent decades. We used carbon stable isotope ratios $\left(\delta^{13} \mathrm{C}\right)$ and nitrogen stable isotope ratios $\left(\delta^{15} \mathrm{~N}\right)$ to assess possible changes in soil organic matter dynamics under such land use modifications. This study aimed to evaluate the differences in soil $\delta^{13} \mathrm{C}$ and $\delta^{15} \mathrm{~N}$ and $\mathrm{C}$ and $\mathrm{N}$ stocks between native vegetation and agricultural or pasture areas in different locations of a plateau in the savannas of Central Brazil. We sampled soil up to $100 \mathrm{~cm}$ depth in pasture areas in the summit of the plateau and no-tillage and conventional tillage on the border of a plateau, as well as soils under native vegetation in both landscape locations. Both soil $\delta^{13} \mathrm{C}$ and $\delta^{15} \mathrm{~N}$, and $\mathrm{C}$ and $\mathrm{N}$ stocks showed no differences between land uses. The different relationships between $\delta^{15} \mathrm{~N}$ and $\mathrm{C} / \mathrm{N}$ ratio at different locations indicated distinct behavior of the soil organic matter between the summit and border of the plateau. Therefore, in addition to land-use, landscape location contributes to both $\delta^{13} \mathrm{C}$ and $\delta^{15} \mathrm{~N}$, and $\mathrm{C}$ and $\mathrm{N}$ stocks in the soil of the plateau.
\end{abstract}

\section{R E S U M O}

Carbono e nitrogênio do solo sob diferentes usos e posições na paisagem no Brasil central.

No Brasil Central, os planaltos são a forma geomorfológica mais comum e vêm sofrendo intensa conversão de vegetação nativa em pastagem e agricultura nas últimas décadas. Os isótopos estáveis de carbono $\left(\delta^{13} \mathrm{C}\right)$ e de nitrogênio $\left(\delta^{15} \mathrm{~N}\right)$ foram usados neste estudo para acessar possíveis mudanças na dinâmica da matéria orgânica no solo nestas áreas convertidas. Este estudo teve como objetivo avaliar as diferenças no $\delta^{13} \mathrm{C}$ e no $\delta^{15} \mathrm{~N}$ e nos estoques $\mathrm{C}$ e $\mathrm{N}$ do solo entre a vegetação nativa e áreas agrícolas ou de pastagem em diferentes posições de um planalto nas savanas do Brasil Central. Foram coletadas amostras de solo até $100 \mathrm{~cm}$ de profundidade em áreas de pastagem no topo e plantio direto e convencional na borda do planalto, bem como solos sob vegetação nativa em ambas as posições. O $\delta^{13} \mathrm{C}$, o $\delta^{15} \mathrm{~N} \mathrm{e}$ os estoques de $\mathrm{C}$ e $\mathrm{N}$ não mostraram diferenças entre os usos da terra. As diferentes relações entre $\delta^{15} \mathrm{~N}$ e a razão $\mathrm{C} / \mathrm{N}$ em cada posição indicam um comportamento distinto da matéria orgânica do solo entre o topo e a borda do planalto. Portanto, além do uso da terra, a posição da paisagem contribui para os valores de $\delta^{13} \mathrm{C}$ e $\delta^{15} \mathrm{~N}$ e os estoques de $\mathrm{C}$ e $\mathrm{N}$ no solo desse planalto. 


\section{INTRODUCTION}

Land use changes (LUC) imply modifications in both carbon $(\mathrm{C})$ and nitrogen $(\mathrm{N})$ cycling, and consequently, in the functioning of ecosystems (Steffen et al., 2015). The differences due to LUC can occur through the increase or reduction of $\mathrm{C}$ and $\mathrm{N}$ stocks (Guareschi et al., 2014), which vary with the intensity of the changes and the management provided to each area (Cecagno et al., 2018; Marinho Junior et al., 2020). In soil research, $\mathrm{C}$ stable isotope ratios $\left(\delta^{13} \mathrm{C}\right)$ and $\mathrm{N}$ stable isotope ratios $\left(\delta^{15} \mathrm{~N}\right)$ can integrate soil organic matter dynamics over decades (Alves et al., 2016; Guareschi et al., 2014).

Dynamics of $\mathrm{C}$ and $\mathrm{N}$ also is affected by geomorphology variables. Studies have observed a relationship between landscape location and the $\delta^{13} \mathrm{C}$ (Doetterl et al., 2016) and the $\delta^{15} \mathrm{~N}$ in soil (Weintraub et al., 2015), given that LUC can influence behavior of the organic matter (Mudge et al., 2014). Guimarães et al. (2021) showed differences in organic matter content according to the landscape location and the soil characteristics. Texture and mineralogy also influence soil properties and organic matter behavior (Craine et al., 2015; Singh et al., 2017). Therefore, different landscape locations are determinant of the ecosystem structure and functioning (Arruda et al., 2015), affecting physical, chemical and microbiological attributes of soils (GamaRodrigues et al., 2018).

Plateaus are the most abundant geomorphologic forms of Brazilian savannas (Sano et al., 2019). Due to ease of access for farm machinery, soil depth and being well-drained, savanna plateaus have been undergoing intense conversion from native vegetation to agriculture and pasture. The Central Brazilian savannas (locally named as Cerrado) cover $22 \%$ of the Brazilian territory and its one of the most biologically diverse savannas on the planet (Batlle-Bayer et al., 2010).

The insertion of crops and pastures modify an area's microclimatic conditions, which may lead to differences in decomposition rates and chemical reactions in the soil, leading to different levels of organic soil C (Babu et al., 2020; Soares et al., 2019) affecting C stocks (Alves et al., 2016; Marinho Junior et al. 2020). In the Cerrado, the $C$ stock (Gmach et al., 2018) and N stock (Oliveira et al., 2016) decreases with the transformation of the native area into pasture and plantation areas in surface soils. Vegetal cover, landscape locations and soil characteristics are important regulators of water and nutrient losses in tropical regions (Guimarães et al., 2021). Therefore, it is fundamental to understand the dynamics of soil organic matter before LUC in different landscape locations (Guimarães et al., 2021; Santos et al., 2014). In this context, the objective of this study was to evaluate the differences in soil $\delta^{13} \mathrm{C}$ and $\delta^{15} \mathrm{~N}$ and $\mathrm{C}$ and $\mathrm{N}$ stocks between native vegetation and agricultural or pasture in different locations of a plateau in the savannas of Central Brazil.

\section{MATERIAL AND METHODS}

\section{Study area}

The study area comprises the experimental basin of the Sarandi stream (between $-47^{\circ} ; 42^{\prime}$; $00^{\prime \prime}$ and $-47^{\circ}$; 48'; 00"; $-15^{\circ} ; 34^{\prime}$; 00" and $-15^{\circ}$; 38'; 00"), whose source is located in Planaltina, Distrito Federal, Brazil, with altitudes between 930 and 1,270 $\mathrm{m}$ (Figure 1). The predominant climate is Aw (Köppen), with two well-defined seasons of rainy and dry. The rainy season is between October and April, and the dry season is between May and September. The annual precipitation is greater than $1,500 \mathrm{~mm}$, with temperature varying between $13{ }^{\circ} \mathrm{C}$ to $28^{\circ} \mathrm{C}$.
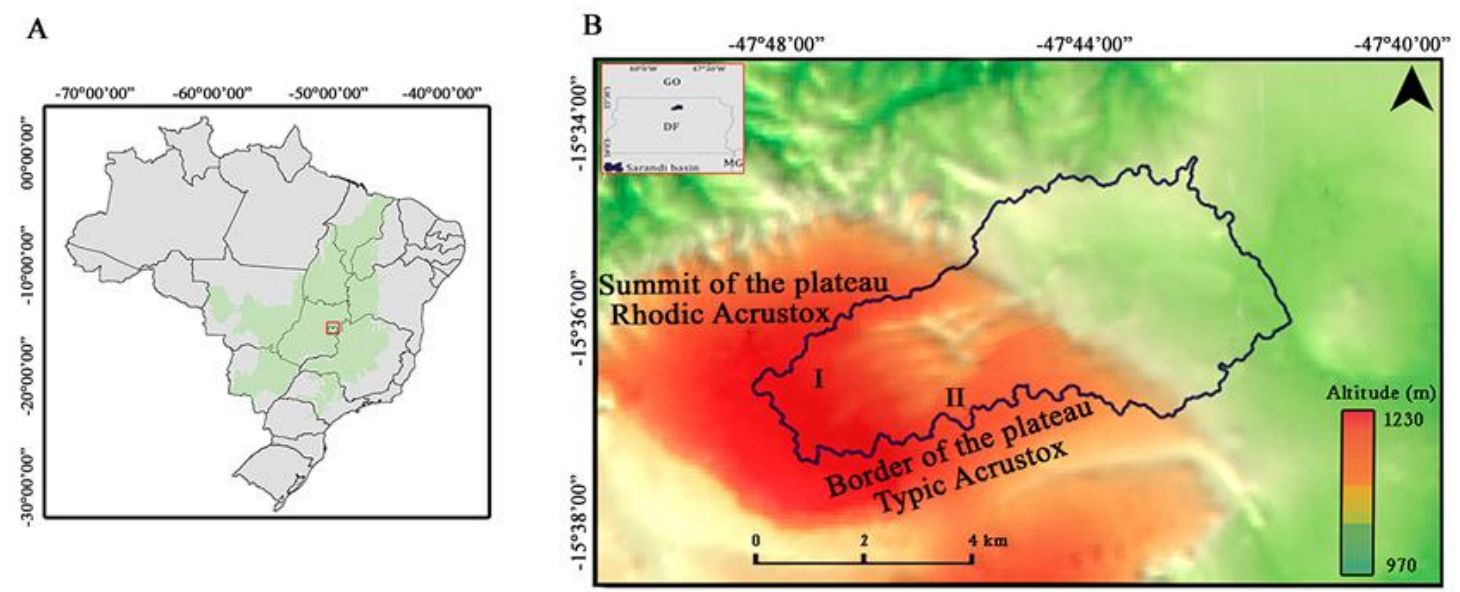

Figure 1 - Location of the Sarandi basin in the Brazilian savanna, north of Distrito Federal (Brasilia), Brazil (A), and sample points on the summit of the plateau - area I; and border of the plateau - area II (B). 
The Sarandi stream flows into the Ribeirão Mestre d'Armas (Sena-Souza et al., 2014), which is one of the most important tributaries of the São Bartolomeu river, which contributes significantly to the formation of the Paraná river basin, within the Planalto Central ecoregion (Sano et al., 2019). The predominant soils are Oxisols, with the presence of Cambisol and Hydromorphic soils, with characteristics that vary according to the relief type where each one is inserted (Lima et al., 2014).

The geology of the region consists mainly of metasedimentary rocks of the Paranoá group (Sena-Souza et al., 2014). The basin displays two flatland surfaces, representative of the Central Plateau related to the South American cycles, formed by plateaus, and the Velhas, related to the lowlands. Soils on the plateaus are older, weathered, and rich in gibbsite, whereas soils on the lowlands are younger, less weathered, and rich in kaolinite (Reatto et al., 2008). The plateaus are formed by flat reliefs and with the predominance of rectilinear and convex forms, with altitudes between 1,100 and 1,200 $\mathrm{m}$.

The soils in the basin are organized according to their location on the landscape: Rhodic Acrustox (Latossolo Vermelho) on the summit of the plateau, and Typic Acrustox (Latossolo Vermelho-Amarelo) on the border of the plateau (Lima et al., 2014). The basin has 55\% anthropogenic coverage, $44.7 \%$ natural coverage, and $0.3 \%$ water bodies. Most of the anthropized area is occupied by pasture (28.7\%) and agriculture $(21.3 \%)$. Among the natural areas, the savanna physiognomy predominates with $27 \%$, while forest formation corresponds to $7 \%$ and other formations to $10 \%$ of the basin.

\section{Soil collection and analysis}

Sample point choices were based on the landscape location and land use of the Sarandi basin (Figure 1). Two natural areas, one pasture, and two agricultural areas were selected, divided into no-tillage and conventional tillage. NVSP: Native vegetation on the summit of the plateau; PSP: Pasture on the summit of plateau; NVBP: Native vegetation on the border of plateau; NTBP: No-tillage on the border of plateau, currently with maize crop; and CTBP: Conventional tillage on the border of plateau, currently with maize crop (Table 1). The NVSP and NVBP are Cerrado stricto sensu, which displays a combination of tree species, shrubs, and grasses. The PSP is a pasture area that was abandoned 20 years ago, after intensive grazing. The NTBP and CTBP are crop rotations, with maize and soybeans employed for 25 years, without preparing the soil between the crops, following the no-tillage system and the conventional tillage, respectively.

Table 1 - Characteristics of sample areas in a plateau in the Sarandi basin, north of the Distrito Federal, Brazil.

\begin{tabular}{|c|c|c|c|c|c|}
\hline Area & Landscape location & Current cover & Soil type & $\begin{array}{c}\text { Latitude } \\
\text { (degrees, } \\
\text { minutes, and } \\
\text { seconds) } \\
\end{array}$ & $\begin{array}{l}\text { Longitude } \\
\text { (degrees, } \\
\text { minutes, and } \\
\text { seconds) } \\
\end{array}$ \\
\hline NVSP & Summit of the plateau & $\begin{array}{l}\text { Cerrado sensu } \\
\quad \text { stricto }\end{array}$ & Rhodic Acrustox & $-15^{\circ} 36^{\prime} 25.2^{\prime \prime}$ & $-47^{\circ} 46^{\prime} 55.2^{\prime \prime}$ \\
\hline PSP & Summit of the plateau & Pasture & Rhodic Acrustox & $-15^{\circ} 36^{\prime} 46.8^{\prime \prime}$ & $-47^{\circ} 46^{\prime} 48.0^{\prime \prime}$ \\
\hline NVBP & Border of the plateau & $\begin{array}{l}\text { Cerrado sensu } \\
\quad \text { stricto }\end{array}$ & Typic Acrustox & $-15^{\circ} 36^{\prime} 39.6^{\prime \prime}$ & $-47^{\circ} 44^{\prime} 42.0^{\prime \prime}$ \\
\hline NTBP & Border of the plateau & No-tillage & Typic Acrustox & $-15^{\circ} 36^{\prime} 28.8^{\prime \prime}$ & $-47^{\circ} 44^{\prime} 31.2^{\prime \prime}$ \\
\hline CTBP & Border of the plateau & $\begin{array}{c}\text { Conventional } \\
\text { tillage }\end{array}$ & Typic Acrustox & $-15^{\circ} 36^{\prime} 32.4^{\prime \prime}$ & $-47^{\circ} 44^{\prime} 34.8^{\prime \prime}$ \\
\hline
\end{tabular}

NVSP: Native vegetation on the summit of the plateau; PSP: Pasture on the summit of the plateau; NVBP: Native vegetation on the border of the plateau; NTBP: No-tillage on the border of the plateau, currently with maize crop; CTBP: Conventional tillage on the border of plateau, currently with maize crop.

In each area, three soil profile samples equidistant from each other were collected at eight depth intervals $(0-5,5-10,10-20,20-30,30-40$, $40-60,60-80$ and $80-100 \mathrm{~cm}$ ). Soil samples were collected employing an auger type for undeformed samples and a Dutch auger type for deformed samples. Samples were air-dried and passed through a $2 \mathrm{~mm}$ mesh sieve. Subsequently, physical, and chemical analyses were performed. The texture was calculated via the pipette method for normal soils, described by Embrapa (1997), the active acidity was calculated via $\mathrm{pH}$ in $\mathrm{H}_{2} \mathrm{O}$. Cation Exchange Capacity (CEC), phosphorus $(\mathrm{P})$ and potassium $(\mathrm{K})$ were extracted 
via Mehlich $^{-1}$ method. Calcium (Ca), magnesium $(\mathrm{Mg})$ and aluminum $(\mathrm{Al})$ were determined by $\mathrm{KCl}^{-}$ ${ }^{1} \mathrm{~mol} / \mathrm{L}$ solution and determined by titration, according to Embrapa (1997). Only values from 0 to $20 \mathrm{~cm}$ depth were presented due to the nondetection of some elements in the deeper layers.

The $\mathrm{C}$ and $\mathrm{N}$ concentrations were analyzed via an elemental analyzer, where dry soil samples were milled, and sub-samples between 20 and 100 $\mathrm{mg}$ were weighed and packed in aluminum capsules. These capsules were placed in an elemental analyzer, which determines the concentration of carbon and nitrogen, enabling the $\mathrm{C} / \mathrm{N}$ ratio calculation by dividing the two concentrations. The $\delta^{15} \mathrm{~N}$ and $\delta^{13} \mathrm{C}$ were supplied by a mass spectrometer for isotopic ratios (Thermo Quest Finnigan Delta-Plus) coupled to the elemental analyzer. The $\delta^{15} \mathrm{~N}$ and $\delta^{13} \mathrm{C}$ expressed the proportion of ${ }^{15} \mathrm{~N} /{ }^{14} \mathrm{~N}$ and ${ }^{13} \mathrm{C} /{ }^{12} \mathrm{C}$ in the sample ( $\mathrm{R}$ sample), comparatively to international standards, the isotopic composition of atmosphere $\mathrm{N}$ and the $\mathrm{C}$ of Pee Dee Belemnite (PDB), in deviations per thousand (\%): $\delta=(\mathrm{R}$ sample / R standard -1) x 1000. These analyses were carried out in the Isotopic Ecology laboratory, CENA/USP.

Soil density was calculated by the centrifuge method, where the samples are saturated with water, weighed, placed in a centrifuge for two hours, and weighed again. The $\mathrm{C}$ stocks of each depth interval in all studied areas were calculated through Veldkamp's expression (1994), where C concentration, $\mathrm{CO}\left(\mathrm{g}^{\mathrm{kg}} \mathrm{kg}^{-1}\right)$, was converted in $\left(\mathrm{kg} \cdot \mathrm{kg}^{-1}\right)$ and, after, in C stock $\left(\mathrm{Mg}^{-} \mathrm{ha}^{-1}\right)$, based on

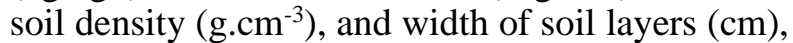
(Equation 1). We calculated mean and standard deviation Mean (SD) of three profiles of each area to represent studied areas. $\mathrm{N}$ stocks were calculated in a similar form. The $\mathrm{C}$ and $\mathrm{N}$ stocks were adjusted for intervals at $40 \mathrm{~cm}$, using the method of Assad et al. (2013). Carbon and nitrogen stocks were calculated up to $40 \mathrm{~cm}$ depth due to the influence of LUC being concentrated on topsoil.

C Stock $=(\mathrm{CO} \times$ Ds $\mathrm{x} \mathrm{e}) / 10$

Eq. 1

Where:

C Stock Organic C stock at a predetermined depth $\left(\mathrm{Mg} \mathrm{ha}^{-1}\right)$

$\mathrm{CO}$ Organic $\mathrm{C}$ concentration at the sampled depth $\left(\mathrm{g} \mathrm{kg}^{-1}\right)$

Ds Depth soil density $\left(\mathrm{kg} \cdot \mathrm{dm}^{-3}\right)$

E thickness of the layer considered (cm)

The total stock, considering all the layers, was calculated similarly to that employed by Assad et al. (2013), which considers the difference between the mass of the reference area and the mass of cultivated areas for each soil layer.

Both the isotope data and the carbon and nitrogen stocks underwent the Shapiro-Wilk normality test. After confirming the normality of the isotope data, the variance analysis ANOVA of repeated measurements was employed, followed by the Tukey test, which evaluated the significance of the differences found between the different soil depth intervals and land cover types. For carbon and nitrogen stocks up to $40 \mathrm{~cm}$ depth, the Mann-Whitney tests were applied on the summit of the plateau and Kruskal-Wallis on the border of the plateau. For all analyses performed, differences up to $5 \%$ were considered significant. Finally, a linear regression was performed between $\mathrm{C} / \mathrm{N}$ ratio and $\delta^{15} \mathrm{~N}$ data. Statistical analyses were performed using the $\mathrm{R}$ statistical program.

\section{RESULTS}

The soils of a plateau in the Sarandi basin presented higher clay content in NVSP and lower in NTBP. The sand was higher in CTBP and lower in NVSP. The silt content ranged between $10.7 \%$ in CTBP and $21.8 \%$ in NTBP; and (Table 2).

Table 2 - Soil texture (mean \pm SD) in different land use and landscape locations of a plateau in the Sarandi basin, north of Distrito Federal, Brazil.

\begin{tabular}{lccc}
\hline Area & Clay $(\%)$ & Silt $(\%)$ & Sand $(\%)$ \\
\hline NVSP & $67.3 \pm 2.8$ & $13.1 \pm 2.8$ & $19.6 \pm 3.7$ \\
PSP & $67.3 \pm 3.7$ & $12.8 \pm 3.9$ & $19.9 \pm 5.6$ \\
NVBP & $64.7 \pm 5.4$ & $12.5 \pm 4.9$ & $22.8 \pm 3.0$ \\
NTBP & $47.0 \pm 8.5$ & $21.8 \pm 5.9$ & $31.2 \pm 4.1$ \\
CTBP & $57.7 \pm 2.7$ & $10.7 \pm 2.3$ & $31.7 \pm 4.4$
\end{tabular}

NVSP: Native vegetation on the summit of the plateau; PSP: Pasture on the summit of the plateau; NVBP: Native vegetation on the border of the plateau; NTBP: No-tillage on the border of the plateau, currently with maize crop; CTBP: Conventional tillage on the border of the plateau, currently with maize crop. 
The $\mathrm{pH}$ ranged from 5.0 in $\mathrm{PSP}$ to 5.9 in NTBP. P, Al, CEC, and SOM higher values were in natural areas (NVSP and NVBP), while higher values of $\mathrm{P}, \mathrm{Ca}$, and $\mathrm{K}$ were found in agricultural areas (Table 3).

Table 3 - Soil chemical characteristics (mean \pm SD) under different land uses and landscape locations in a plateau in the Sarandi basin, north of Distrito Federal, Brazil.

\begin{tabular}{lcccccccc}
\hline Area & $\mathrm{pH} \mathrm{H} \mathrm{H}_{2} \mathrm{O}$ & $\mathrm{P}$ & $\mathrm{Ca}$ & $\mathrm{Mg}$ & $\mathrm{K}$ & $\mathrm{Al}$ & $\mathrm{CEC}$ & $\mathrm{SOM}$ \\
& & & & & & \\
$\left(\mathrm{mg} . \mathrm{dm}^{-3}\right)$ & & & & & & \\
& & & & & & & \\
NVSP & $5.2 \pm 0.1$ & $0.1 \pm 0.1$ & $0.1 \pm 0.1$ & $0.1 \pm 0.0$ & $0.1 \pm 0.0$ & $0.3 \pm 0.2$ & $5.9 \pm 1.0$ & $3.4 \pm 0.6$ \\
PSP & $5.0 \pm 0.1$ & $0.2 \pm 0.4$ & $0.2 \pm 0.2$ & $0.1 \pm 0.0$ & $0.0 \pm 0.0$ & $0.3 \pm 0.1$ & $5.4 \pm 0.6$ & $2.6 \pm 0.3$ \\
NVBP & $5.1 \pm 0.1$ & $0.7 \pm 0.3$ & $0.2 \pm 0.2$ & $0.1 \pm 0.1$ & $0.1 \pm 0.0$ & $0.6 \pm 0.3$ & $6.7 \pm 1.4$ & $3.2 \pm 0.9$ \\
NTBP & $5.9 \pm 0.4$ & $11.6 \pm 10.2$ & $2.7 \pm 1.2$ & $0.1 \pm 0.4$ & $0.2 \pm 0.1$ & $0.0 \pm 0.1$ & $7.5 \pm 0.8$ & $3.1 \pm 0.6$ \\
CTBP & $5.7 \pm 0.2$ & $13.5 \pm 6.5$ & $1.7 \pm 0.4$ & $0.4 \pm 0.1$ & $0.2 \pm 0.1$ & $0.0 \pm 0.1$ & $6.3 \pm 1.3$ & $2.6 \pm 0.6$ \\
\hline
\end{tabular}

$\mathrm{pH}$ in $\mathrm{H}_{2} \mathrm{O}$, phosphorus $(\mathrm{P})$, calcium $(\mathrm{Ca})$, magnesium $(\mathrm{Mg})$, potassium $(\mathrm{K})$, aluminum (Al), cationic exchange capacity (CEC), and soil organic matter (SOM). NVSP: Native vegetation on the summit of the plateau; PSP: Pasture on the summit of the plateau; NVBP: Native vegetation on the border of the plateau; NTBP: No-tillage on the border of the plateau, currently with maize crop; CTBP: Conventional tillage on the border of the plateau, currently with maize crop. Values up to $20 \mathrm{~cm}$ depth.

Soil C stocks up to $40 \mathrm{~cm}$ depth present differences between the natural area and the pasture on the summit of the plateau ( $p<$ $0.05)$. On the border of the plateau, there was also no difference. The $\mathrm{C}$ stock is higher $(p<0.05)$ in native area on the summit (NVSP) than at the border (NVBP) of the plateau (Figure 2A). Soil nitrogen stocks up to $40 \mathrm{~cm}$ depth show differences between the natural area and pasture

A

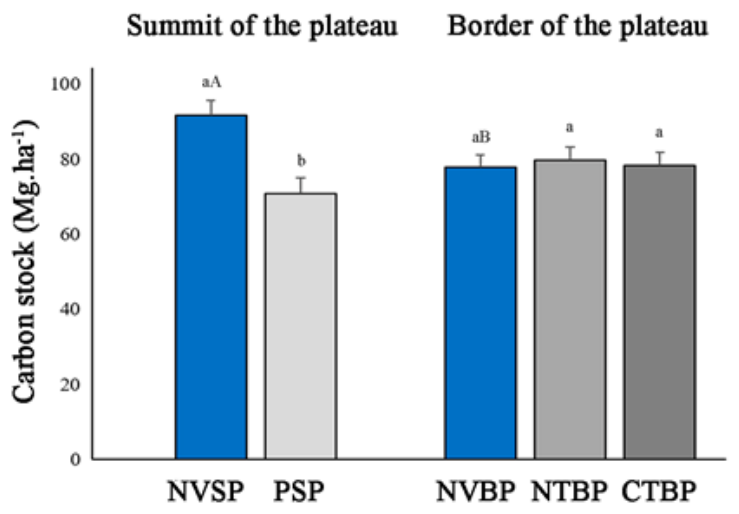

on the summit of plateaus $(p<0.05)$. On the border of the plateau, there was no difference between the Cerrado stricto sensu area and the conventional tillage and no-tillage areas. The $\mathrm{N}$ stock is higher $(p<0.05)$ in the native area on the summit (NVSP) than on the border (NVBP) of the plateau (Figure 2B).

\section{B}

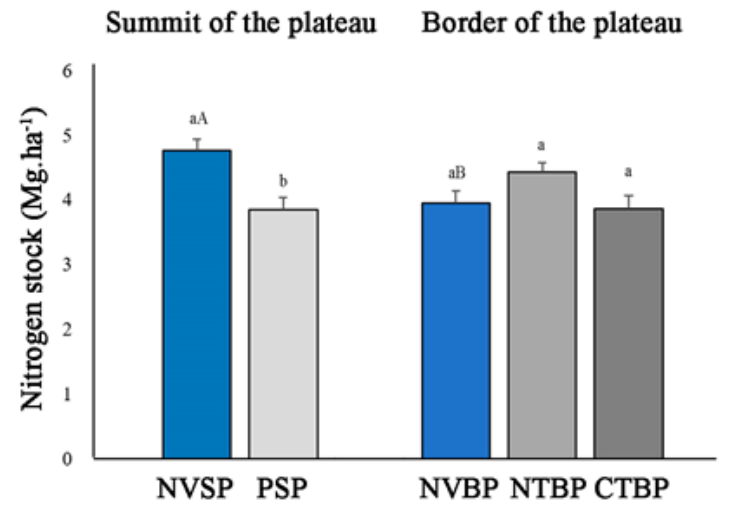

NVSP: Native vegetation on the summit of the plateau; PSP: Pasture on the summit of the plateau; NVBP: Native vegetation on the border of the plateau; NTBP: No-tillage on the border of the plateau, currently with maize crop; CTBP: Conventional tillage on the border of the plateau, currently with maize crop. Lowercase letters indicate the differences between land uses in the same landscape location. Capital letters indicate the differences between native areas in the different landscape locations.

Figure 2 - Soil carbon stock (A), and soil nitrogen stock (B) up to $40 \mathrm{~cm}$ depth (average \pm SD) in different land uses at the summit, and the border of a plateau in the Sarandi basin, north of Distrito Federal, Brazil.

The $\delta^{13} \mathrm{C}$ ranged from $-21.7 \%$ in PSP up to 5 $\mathrm{cm}$ depth to $-19.3 \%$ in NVSP between the 80 and $100 \mathrm{~cm}$ depth interval. There was a statistically significant difference between soil depth only PSP $(p<0.05)$. There was no difference between isotopic ratios for different land uses on the summit of the plateau and the border of the plateau along with the entire soil profile (Figure $3)$. 
A

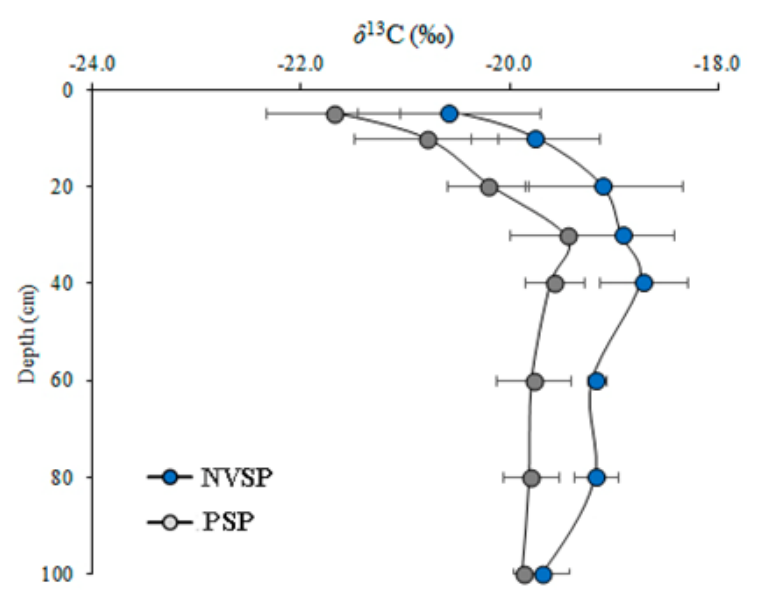

B

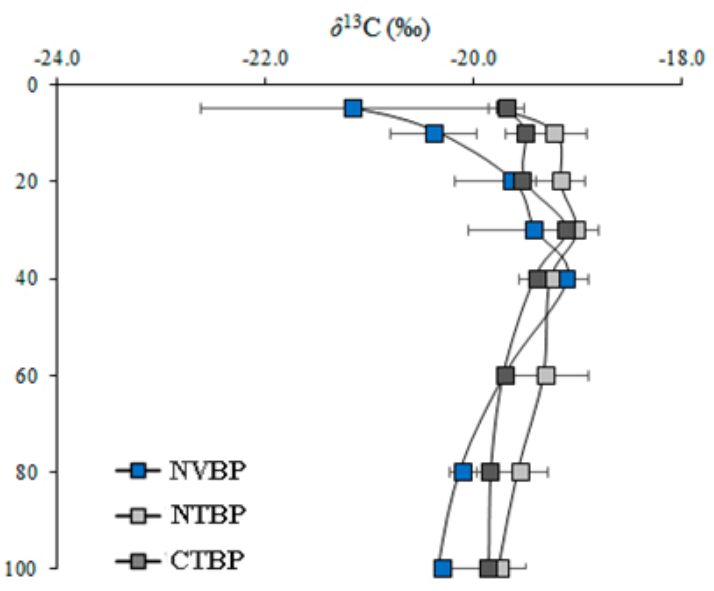

NVSP: Native vegetation on the summit of the plateau; PSP: Pasture on the summit of the plateau; NVBP: Native vegetation on the border of the plateau; NTBP: No-tillage on the border of the plateau, currently with maize crop; CTBP: Conventional tillage on the border of the plateau, currently with maize crop.

Figure 3 - Soil $\delta^{13} \mathrm{C}$ (average $\pm \mathrm{SD}$ ) up to $100 \mathrm{~cm}$ depth, for different land uses on the summit of the plateau (A), and the border of a plateau (B) in the Sarandi basin, north of Distrito Federal, Brazil.

The $\delta^{15} \mathrm{~N}$ ranged from $5.4 \%$ in NTBP in topsoil to $11.1 \%$ in NVBP between the 80 and 100 $\mathrm{cm}$. There was a statistically significant difference between soil depth in all areas $(p<0.05)$. There was no difference between isotopic ratios for different land uses on the summit of the plateau and the border of the plateau along with the entire soil profile (Figure 4).
A

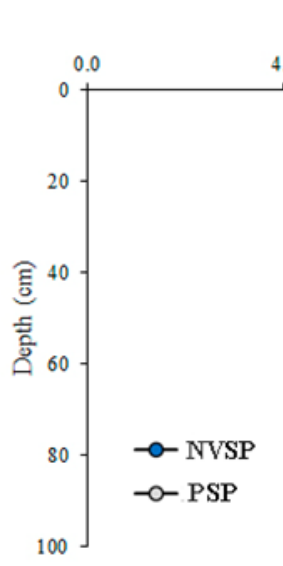

B

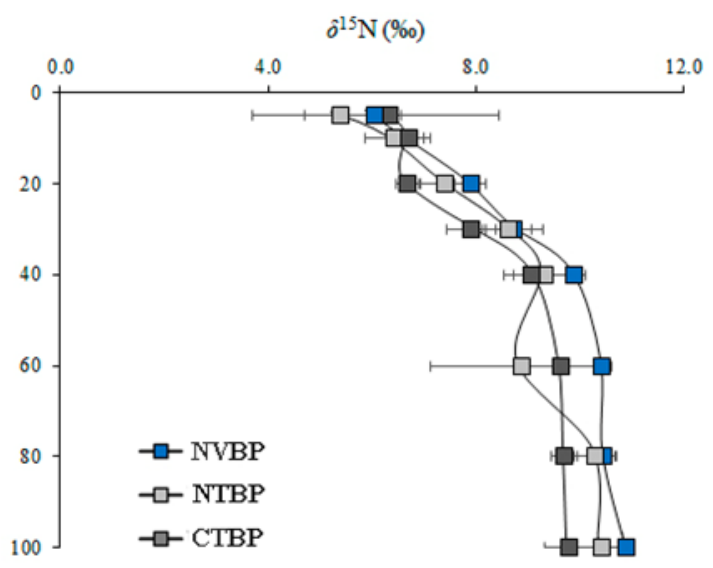

NVSP: Native vegetation on the summit of the plateau; PSP: Pasture on the summit of the plateau; NVBP: Native vegetation on the border of the plateau; NTBP: No-tillage on the border of the plateau, currently with maize crop; CTBP: Conventional tillage on the border of the plateau, currently with maize crop.

Figure 4 - Soil $\delta^{15} \mathrm{~N}$ (average $\pm \mathrm{SD}$ ) up to $100 \mathrm{~cm}$ depth, for different land uses in the summit of the plateau (A), and the border of a plateau (B) in the Sarandi basin, north of Distrito Federal, Brazil.

The regression between the $\mathrm{C} / \mathrm{N}$ ratio values and the soil $\delta^{15} \mathrm{~N}$ on the summit of a plateau displayed $\mathrm{R}^{2}$ of 0.08 in NVSP and 0.03 in PSP without connection for both areas. On the border of the plateau, the $\mathrm{R}^{2}$ was 0.009 in NVBP, 0.70 in NTBP and 0.10 CTBP, and only in NTBP, was there a statistically significant correlation $(p<$ 0.05) (Figure 5). 
A

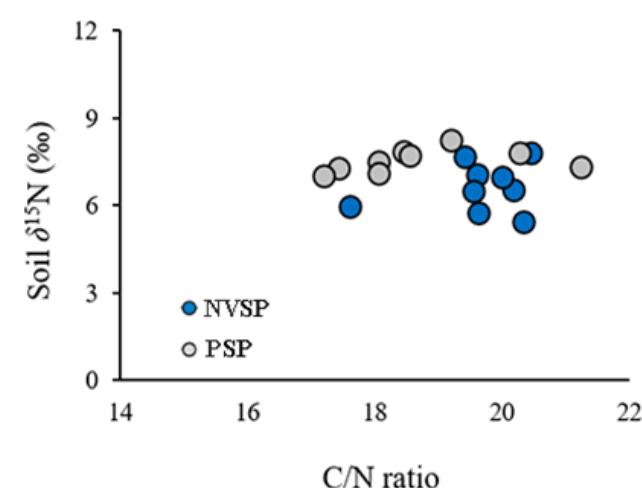

B

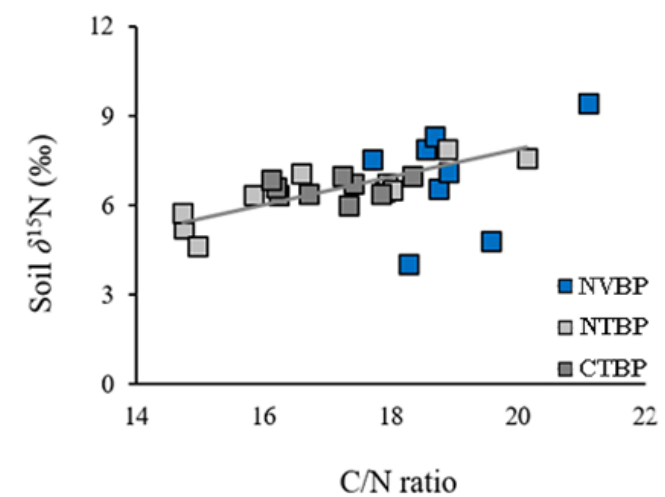

NVSP: Native vegetation on the summit of the plateau; PSP: Pasture on the summit of the plateau; NVBP: Native vegetation on the border of the plateau; NTBP: No-tillage on the border of the plateau, currently with maize crop; CTBP: Conventional tillage on the border of the plateau, currently with maize crop.

Figure 5 - Relationship between soil $\delta^{15} \mathrm{~N}$ and $\mathrm{C} / \mathrm{N}$ ratio up to $40 \mathrm{~cm}$ depth, for different land uses in the summit of the plateau (A), and the border of a plateau (B) in the Sarandi basin, north of Distrito Federal, Brazil.

\section{DISCUSSION}

The Cerrado stricto sensu displays a combination of tree species, shrubs, and grasses, so it possesses a $\delta^{13} \mathrm{C}$ signal that stands between typical values of $\mathrm{C}_{3}(-22 \%$ to $-35 \%)$ and $\mathrm{C}_{4}(-$ $12 \%$ to $-18 \%$ ) plants. Grasses and trees have different photosynthetic processes, and soil $\delta^{13} \mathrm{C}$ values reflect the contribution of cover plants (Oliveira et al., 2016). Our results corroborate the importance of the herbaceous stratum contribution to the soil organic matter in the Brazilian savanna, with similar values in native areas, regardless of landscape location and soil type.

On the summit of the plateau, both the NVSP and the PSP displayed similar values, provided by a combination of $\mathrm{C}_{3}$ and $\mathrm{C}_{4}$ plants. However, the pasture has only grasses with the $\mathrm{C}_{4}$ photosynthetic cycle and should provide a higher $\delta^{13} \mathrm{C}$ signal on the topsoil, such as the values found in work such as Assad et al. (2013), where there is a more pronounced $\mathrm{C}_{4}$ signal coming from the cover plants. The organic matter deposited by grasses is more rapidly consumed by soil biota. This does not happen because of the management intensity of pasture, where cattle are no longer present, which allows the emergence of native shrub and tree species, approximating the values of $\delta^{13} \mathrm{C}$ in the soils of native and pasture areas. Typical values of Cerrado also occur on the border of plateaus along with the entire soil profile, as crop rotation like soybean and maize promote a combination of $\mathrm{C}_{3}$ and $\mathrm{C}_{4}$ sources in farming areas. However, there are differences between natural and no-tillage area along with soil depth, due to the higher incorporation of $\mathrm{C}_{4}$ organic matter in soils under the no-tillage area (Oliveira et al., 2016).
The similarity in the $\delta^{15} \mathrm{~N}$ soil along with the entire profile both for NVSP and PSP, on the summit of the plateau, although the establishment of pastures often enriches the soil with $\delta^{15} \mathrm{~N}$ (Mudge et al., 2014). The border of the plateau also displays similar $\delta^{15} \mathrm{~N}$ among the land uses, even with possible increased mineralization rates caused by the crops (Guareschi et al., 2014; Oliveira et al., 2016). In the case of this study, both conventional and no-tillage are characterized by crop rotation. Because of this, the soil also records nitrogen incorporated into the soil in legume crops such as soybean and bean. These crops incorporate atmospheric $\mathrm{N}$ into the soil, which has $\delta^{15} \mathrm{~N}$ close to $0 \%$ (Högberg, 1997), which inhibits the possible increase caused by increased $\mathrm{N}$ cycling in the soil and the deposition of inputs in agricultural areas.

Well-managed pastures may maintain (Alves et al., 2016; Cecagno et al., 2018) or increase the C stock in the soil (D'Andrea et al., 2004) in relation to a native area, explained by the management difference for each pasture (Marinho Junior et al., 2020). However, our results show a reduction in $C$ and $\mathrm{N}$ stocks in the pasture at the summit of the plateau. The absence of arboreal input in the pasture reduces the deposition of organic matter in the soil (Gmach et al., 2018). In addition, this area does not receive an addition of nutrients, which prevents faster growth of plant species. On the border of the plateau, there were no differences in the $\mathrm{C}$ and $\mathrm{N}$ stocks between the natural area and the plantation areas, similar to the work of D'Andrea et al. (2004). Although the substitution of natural vegetation by the no-tillage system can increase the soil carbon stock while conventional tillage tends to reduce this stock (Guareschi et al., 2014). In this case, the intensity of crops is not 
sufficient to alter the values of $\mathrm{C}$ and $\mathrm{N}$ in the soil of the Brazilian savannas.

The higher $\mathrm{C}$ and $\mathrm{N}$ stocks on the summit than on the border of the plateau indicate that the top soil has a greater capacity to retain organic matter in native areas, although the physical and chemical attributes are similar in the landscape. Border soils tend to be more influenced by groundwater and erosion processes, in addition to being shallower, which also explains the difference in soil type (Arruda et al., 2015; Guimarães et al., 2021). These results demonstrate that in addition to land use, other factors influence the dynamics of organic matter in the soil of this plateau (GamaRodrigues et al., 2018). This is corroborated by the difference in the ratio of $\delta^{15} \mathrm{~N}$ to the $\mathrm{C} / \mathrm{N}$ ratio at each location in the landscape. Global studies indicate that there is a negative relationship between $\delta^{15} \mathrm{~N}$ and the $\mathrm{C} / \mathrm{N}$ ratio of the soil, since lower values of the $\mathrm{C} / \mathrm{N}$ ratio indicate an increase in the processes of mineralization and decomposition and raise the soil $\delta^{15} \mathrm{~N}$ (Craine et al., 2015). However, our results show that there is no significant relationship between these attributes in the summit of plateau, while there is a positive relationship on the border of plateau, which demonstrates that other factors may be controlling the dynamics of organic matter in these environments.

In our study, relationships between soil $\delta^{15} \mathrm{~N}$ and clay were not found, which differs from global trends (Craine et al., 2015). However, there is evidence that there is a different dynamic in each location in the landscape, due to the different characteristics of the soil, relationship with water, erosion and decomposition processes (Doetterl et al., 2016; Guimarães et al., 2021; Weintraub et al., 2015). Differences in soil mineralogy may be a controlling factor for SOM in this environment, as noted by Reatto et al. (2008), since it is connected to the way the minerals associate themselves with the SOM in Brazilian savannas. Therefore, the soil dynamic is different in landscape locations, even in native areas, demonstrated by a distinct relationship between the soil $\delta^{15} \mathrm{~N}$ and $\mathrm{C} / \mathrm{N}$ ratio in each landscape location. The insertion of pasture changed the stocks of $\mathrm{C}$ and $\mathrm{N}$, but this did not happen in agricultural areas, due to the low intensity of use or stability of the plateau. The LUC was not sufficient to alter the isotopes of $\mathrm{C}$ and $\mathrm{N}$ in the soil of the plateau of the Sarandi basin.

\section{CONCLUSIONS}

Changes in land use of native vegetation for pasture decrease both $\mathrm{C}$ and $\mathrm{N}$ stocks of soil on the summit of plateau. However, the intensity of the LUC was not sufficient to alter soil $\delta^{13} \mathrm{C}$ and soil $\delta^{15} \mathrm{~N}$ in any landscape location.

The differences in $\mathrm{C}$ and $\mathrm{N}$ stocks between native areas of different locations in the landscape indicated that landscape locations contribute to the dynamics of organic matter in the soil, due to the different soil characteristics and processes.

\section{ACKNOWLEDGMENT}

This study was developed in context of Geocerrado Project "Modelagem de variáveis geoambientais para a caracterização de serviços ambientais no Bioma Cerrado" (02.10.01.015.00.00) by Embrapa Cerrados and CNA. Part this study was financed by the CAPES - Coordenação de Aperfeiçoamento de Pessoal de Nível Superior - Brasil - Finance Code 001 and by $\mathrm{CNPq}$ - Conselho Nacional de Desenvolvimento Científico e Tecnológico (scholarship for first author). Jim Hesson copyedited the manuscript (https://www.academicenglishsolutions.com/editin g-service).

\section{REFERENCES}

Alves RP, Couto Júnior AF, Martins ES, Nardoto GB. Role of soil carbon in the landscape functioning of the Alto São Bartolomeu watershed in the Cerrado region, Brazil. Pesquisa Agropecuária Brasileira, 51 (9): 1241-1251, 2016. https://doi.org/10.1590/s0100-204x2016000900024

Arruda DM, Schaefer CEGR, Corrêa GR, Rodrigues PMS, Duque-Brasil R, Ferreira Jr WG, Oliveira-Filho AT. Landforms and soil attributes determine the vegetation structure in the Brazilian semiarid. Folia Geobot, 50:175-184, 2015. https://doi.org/10.1007/s12224-015-9221-0

Assad ED, Pinto HS, Martins SC, Groppo JD, Salgado PR, Evangelista B, Vasconcellos E, Sano EE, Pavão E, Luna R, Camargo PB, Martinelli LA. Changes in soil carbon stocks in Brazil due to land use: paired site comparisons and a regional pasture soil survey, Biogeosciences, 10: 61416160, 2013. https://doi:10.5194/bg-10-6141-2013

Babu S, Mohapatraa KP, Yadav GS, Lal R, Singh R, Avasthe RK, Das A, Chandra P, Gudadee BA, Kumard A. Soil carbon dynamics in diverse organic land use systems in North Eastern Himalayan ecosystem of India. Catena, 194, 104785, 2020 .

https://doi.org/10.1016/j.catena.2020.104785

Batlle-Bayer L, Batjes NH, Bindraban PS. Changes in organic carbon stocks upon land use conversion in the Brazilian Cerrado: A review. Agriculture, Ecosystems and Environment, v. 137, p. 47-58, 2010. https://doi:10.1016/j.agee.2010.02.003

Brum FT, Pressey RL, Bini LM, Loyola R. Forecasting conservation impact to pinpoint spatial priorities in the Brazilian Cerrado. Biological Conservation, 240: 108283, 2019. 
Bustamante MMC, Medina E, Asner GP, Nardoto GB, Garciamontiel DC. Nitrogen cycling in tropical and temperate savannas. Biogeochemistry, 79: 209-237, 2006. https://doi.10.1007/s10533-006-9006-x

Cecagno D, Gomes MV, Costa SE, Martins AP, Denardin LGO, Bayer C, Anghinoni I, Carvalho PC. Soil organic carbon in an integrated crop-livestock system under different grazing intensities. Revista Brasileira de Ciências Agrárias, v.13, n.3, e5553, 7p, 2018.

https://doi.10.5039/agraria.v13i3a5553

Craine JM, Elmore AJ, Wang L, Augusto L, Baisden WT, Brookshire ENJ, Cramer MD, Hasselquist NJ, Hobbie EA, Kahmen A; Koba11 K, Kranabetter JM, Mack MC, MarinSpiotta E, Mayor JR, Mclauchlan KK, Michelsen A, Nardoto GB, Oliveira RS, Perakis SS, Peri PL, Quesada CA, Richter A,; Schipper LA, Stevenson BA, Turner BL, Viani RAG, Wanek W, Zelle B. Convergence of soil nitrogen isotopes across global climate gradients. Scientific Reports, 5:8280. 8p, 2015. https://doi.10.1038/srep08280

D'Andrea AF, Silva MLN, Curi LN, Guilherme LRG. Estoque de carbono e nitrogênio e formas de nitrogênio mineral em um solo submetido a diferentes sistemas de manejo. Pesquisa Agropecuária Brasileira, 39 (2): 179-186, 2004.

Doetterl S, Berhe AA, Nadeu E, Wang Z, Sommer M, Fiener P. Erosion, deposition and soil carbon: A review of process-level controls, experimental tools and models to address $\mathrm{C}$ cycling in dynamic landscapes. Earth Science Review, 154:102-122, 2016

http://dx.doi.org/10.1016/j.earscirev.2015.12.005

EMBRAPA - Empresa brasileira de Pesquisa Agropecuária. Centro Nacional de Pesquisa de Solos. Manual de métodos de análise de solos. $2^{\text {a }}$ edição revisada e atualizada. Rio de Janeiro, 212p, 1997.

Gama-Rodrigues EF, Araújo SP, Faustino LL, Moreira RV, Paulucio VO, Gama-Rodrigues AC. Atributos físicos, químicos e microbiológicos dos solos sob diferentes usos em topossequências no Noroeste Fluminense. Revista Brasileira de Ciências Agrárias, v.13, n.3, e5543, 9p, 2018. https://doi.10.5039/agraria.v13i3a5543

Gmach MR, Dias BO, Silva CA, Nóbrega JCA, LustosaFilho JF, Siqueira-Neto M. Soil organic matter dynamics and land-use change on Oxisols in the Cerrado, Brazil. Geoderma Regional 14, e00178, 2018.

https://doi.org/10.1016/j.geodrs.2018.e00178

Guareschi RF, Pereira MG, Perin A. Carbono, nitrogênio e abundância natural de $\delta^{13} \mathrm{Ce} \delta^{15} \mathrm{~N}$ em uma cronossequência de agricultura sob plantio direto no Cerrado goiano. Revista Brasileira de Ciências do Solo, 38:1135-1142, 2014.

Högberg P. ${ }^{15} \mathrm{~N}$ natural abundance in soil-plant systems. New Phytol, 137:179-203, 1997.

Lima LA, Reatto A, Roig HL. Soil Mapping of a Small Watershed in a Brazilian Savanna Biome: A Semi-Automatic Approach. Journal of Geographic Information System, 6: 79-87, 2014. https://doi.10.4236/jgis.2014.62009

Marinho Junior JL, Lima DS, Dias JLA, Araujo Filho RN. Análise dos estoques de carbono no solo sob diferentes coberturas vegetais no Brasil (revisão). Journal of Biotechnology and Biodiversity, v.8 n.1 2020.

https://doi.org/10.20873/jbb.uft.cemaf.v8n1.marinhojr
Mudge PL, Schipper LA, Baisden WT, Ghani A, Lewis RW. Changes in soil C, $\mathrm{N}$ and $\delta^{15} \mathrm{~N}$ along three forest-pasture chronosequences in New Zealand. Soil Research, 52: $27-$ 37, 2014. http://dx.doi.org/10.1071/SR13183

Oliveira DMS, Paustian K, Davies CA, Cherubin MR, Franco ALC, Cerri CC, Cerri CEP. Soil carbon changes in areas undergoing expansion of sugarcane into pastures in south-central Brazil. Agriculture, Ecosystems and Environment, 228, 38-48, 2016. http://dx.doi.org/10.1016/j.agee.2016.05.005

Reatto A, Bruand A, Martins ES, Muller F, Silva E, Carvalho Junior O, Brossard M. Variation of the kaolinite and gibbsite content at regional and local scale in Latosols of the Brazilian Central Plateau. Comptes Rendus. Géoscience, 340:741-748, 2008. https://doi.10.1016/j.crte.2008.07.006

Sano EE, Rodrigues AA, Martins ES, Bettiol GM, Bustamante MMC, Bezerra AS, Couto Junior AF, Vasconcelos V, Schüler J, Bolfe EL. Cerrado ecoregions: A spatial framework to assess and prioritize Brazilian savannas environmental diversity for conservation. Journal of Environmental Management, 232:818-828, 2019. https://doi.org/10.1016/j.jenvman.2018.11.108

Santos IL, Caixeta CF, Sousa AA, Figueiredo CC, Ramos MLG, Carvalho AM. Cover plants and mineral nitrogen: Effects on organic matter fractions in an Oxisol under notillage in the Cerrado. Revista. Brasileira de Ciências do Solo, 38:1874-1881, 2014.

Singh M, Sarkar B, Biswas B, Bolan NS, Churchman GJ. Relationship between soil clay mineralogy and carbon protection capacity as influenced by temperature and moisture. Soil Biology and Biochemistry, 109:95-106, 2017. https://doi.org/10.1016/bs.agron.2017.11.001

Sena-Souza JP, Neves G, Reis AM, Alves RP, Santos FL, Kisaka TB, Martins ES, Couto Junior AF. Mapeamento geomorfológico da bacia hidrográfica do ribeirão Mestre d'Armas, Distrito Federal. Espaço \& Geografia, 17, n.1, 71-95, 2014.

Soares DS, Ramos MLG, Marchão RL, Maciel GA, Oliveira AD, Malaquias JV, Carvalho AM. How diversity of crop residues in long-term no-tillage systems affect chemical and microbiological soil properties. Soil \& Tillage Research, 194. 104316, 2019. https://doi.org/10.1016/j.still.2019.104316

Steffen W, Richardson K, Rockström J, Cornell SE, Fetzer I, Bennett EM, Biggs R, Carpenter SR, de Vries W, de Wit CA, Folke C, Gerten D, Heinke J, Mace GM, Persson LM, Ramanathan V, Reyers B, Sörlin S. Planetary boundaries: guiding. Science, 347: 736-747, 2015. https://doi.org/10.1126/science.1259855

Veldkamp E. Organic carbon turnover in three tropical soils under pasture after deforestation. Soil Science Society of America Journal, 58:175-180, 1994.

Weintraub SR, Taylor PG, Porder S, Cleveland CC, Asner GP, Townsend AR. Topographic controls on soil nitrogen availability in a lowland tropical forest. Ecology, 96 (6):1561-1574, 2015. http://dx.doi.org/10.1890/14-0834.1 